\title{
Safety, courts and crime: occupational safety and health prosecutions in the Magistrates' courts
}

\author{
Richard Johnstone B Bus Sci LLB (Hons) PhD, Australian National University/Griffith
}

University, Australia

\begin{abstract}
This paper reports on an empirically based study of occupational safety and health prosecutions in the Magistrates' courts in the State of Victoria, Australia. It examines the way in which the courts construct occupational safety and health issues during prosecutions against alleged offenders, and then theorises the role of the criminal law in health and safety regulation. The paper argues that courts, inspectors, prosecutors and defence counsel are involved in filtering or reshaping occupational safety and health issues during the prosecution process, both pre-trial and in court. An analysis of the pattern of investigation of health and safety offences shows that they are constructed by focusing on 'events', in most cases incidents resulting in injury or death. This 'event focus' ensures that the attention of the parties is drawn to the details of the incident and away from the broader context of the event. This broader context includes the way in which work is organised at the workplace and the quality of occupational safety and health management (the micro context), and the pressures within capitalist production systems for occupational safety and health to be subordinated to production imperatives (the macro context). In particular, during the court-based sentencing process, defence counsel is able to adopt a range of 'isolation' techniques that isolate the incident from its micro and macro contexts, thereby individualising and decontextualising the incident. The paper concludes that the legal system plays a key role in decontextualising and individualising health and safety issues, and that this process is part of the 'architecture' of the legal system, and a direct consequence of the 'form of law'.
\end{abstract}

\section{Key words}

Criminal law, enforcement, prosecution, sentencing

\section{Introduction}

Despite the importance of prosecution in an occupational safety and health $(\mathrm{OSH})$ regulatory regime, and the disquiet at the clear inadequacies of prosecution of those contravening health and safety statutes, ${ }^{1}$ there has been little research into the way in which the courts hear such prosecutions. This study aims to fill this gap, and to build upon a previous study of health and safety prosecutions in Victoria, Australia, from $1885-1979,{ }^{2}$ a study of OSH prosecutions in New South Wales, ${ }^{3}$ and a 1970 English Law Commission study into strict liability and the enforcement of the Factories Act $1961 .^{4}$

The study assumes that crime is a social construction, not a fixed or unchanging phenomenon, and that it is defined and shaped by those who make and enforce the criminal law. ${ }^{5}$ A prosecuted 'case' is 'a construct from an event, not a reproduction of it. ${ }^{6}$ The study also assumes that the construction of health and safety offences by the courts is heavily influenced by pre-trial processes such as pre-trial investigation, case preparation and negotiation. ${ }^{7}$ The study examines pre-trial processes and court proceedings, and its aim is to analyse the way in which the Victorian Magistrates' courts construct health and safety legislation, the 'facts' of health and safety 
offences, and the degree of criminality of those offences when hearing prosecutions for offences under the statutes operative in that state - the Industrial Safety, Health and Welfare Act 1981 (Vic) and the Occupational Health and Safety Act 1985 (Vic). ${ }^{8 *}$ The study examines the period 1983 to 1999 , and data were gathered using a variety of methods, including participant observation of health and safety prosecutors and inspectors; interviews with inspectors, prosecutors and magistrates; analysis of case reports and policy and procedure documents generated by the health and safety inspectorate; and statistical analysis of decided cases and their outcomes.

The paper begins with an overview of the legal framework and historical approach to occupational safety and health enforcement in Australia. It then examines the place of prosecution in the overall enforcement profile of the Victorian health and safety inspectorate, and outlines the types of prosecution 'cases' which emerged from the pre-trial processes of investigation and decision-making. The middle section of the paper analyses the processes by which defence counsel sought to mitigate the criminality of health and safety offences and to shape the factors which magistrates took into account in determining penalties once health and safety charges had been proved, and the strategies developed by prosecutors to counter these arguments. The final section of the paper argues that these strategies are facilitated by the overall 'architecture' of the legal process (including the form of the criminal law) that underpins health and safety offences.

\section{The legal framework and historical approach to enforcement}

\section{The traditional approach to occupational safety and health regulation}

The Australian approach to OSH regulation has strongly resembled that adopted in the United Kingdom. ${ }^{9}$ Since the Factory and Shops Act 1885, the Victorian parliament has enacted statutory standards regulating workplace hazards. Until the 1970s and '80s, these standards have been extremely detailed and technical, focusing mainly on guarding measures to prevent injury to workers operating dangerous machinery. These statutory standards were enforced by a state inspectorate that had the power to prosecute contraventions before the Magistrates' courts, ${ }^{\dagger}$ the lowest level of court in the Australian court hierarchy and responsible for adjudicating most civil and criminal cases. Since the 1830s in England and Wales, and the 1880s in Australia, the Magistrates' courts have played a major part in the process of examining, constructing and adjudicating all aspects of OSH offences, particularly the determination of whether an offence has in fact been committed, and the level of punishment to be exacted.

A notable feature of the early history of Anglo-Australian OSH regulation was the manner in which the offences in the OSH statutes were appended to the existing criminal justice system, without any consideration as to whether the criminal justice system and its procedures - which developed in pre-capitalist UK to regulate the behaviour of individuals - needed to be reconstructed to suit the requirements of an OSH regulatory system aiming to regulate business organisations. A further tension was in the reliance of the UK Factories Acts from

\footnotetext{
*The Australian federal government has no express power to legislate for occupational safety and health. There are 10 major Australian health and safety statutes (one for each state and territory) and two federal statutes (one for employees of federal government departments and Commonwealth authorities, and one for the maritime industry). ${ }^{\dagger}$ Since the 1980s, higher level courts, the intermediate level County Court of Victoria, and the Industrial Relations Commission of New South Wales, have heard more serious OSH prosecutions in Victoria and New South Wales respectively. Nevertheless, most OSH prosecutions in Australia are conducted before magistrates.
} 
$1844,{ }^{10}$ and all of the subsequent Victorian OSH statutes, on strict liability obligations, which signalled to a magistracy steeped in traditional criminal law notions of intention (mens rea) that OSH offences were not 'real crime'. This mindset, of course, mirrored the inspectorate's historically developed views on the 'ambiguity' of OSH crime.

Elsewhere, the author has argued that the early Victorian OSH inspectorates were the heirs of an enforcement tradition that stretched back to mid-nineteenth century UK. ${ }^{2}$ Prosecution was infrequently used by an inspectorate that followed strongly an approach of negotiated compliance through the use of education, advice and persuasion. Carson ${ }^{10}$ has vividly described this preference for informal action for detected contraventions as 'the conventionalisation' of OSH crime, where offences 'are accepted as customary, are rarely subject to criminal prosecution and, indeed, are often not regarded as really constituting crimes at all'. Furthermore, he used the expression 'ambiguity of factory crime' to describe the discontinuity between factory crime and 'real crime'. ${ }^{11}$ The enforcement of OSH standards ultimately rested on the threshold of voluntary compliance within the marketplace, rather than on the threat of externally imposed legal sanctions, which were (and still are) used as a last resort. ${ }^{12,13}$

When prosecution was the favoured approach in Victoria, the statutory focus on requiring dangerous machines to be guarded meant that machinery guarding offences resulting in serious injuries were the most likely to go before the courts. The prosecution statistics in Victoria for the period 1885 to 1979 suggest that the ambiguity and conventionalisation of factory crime not only permeated the inspector's decision-making processes, but also proceedings before magistrates. The maximum fines available for offences under the OSH provisions were very low during the period 1885 to 1979 (in 1979 the maximum fine was $A \$ 2,000$ ). In the period 1900-1919, the fines imposed by the courts averaged 25 per cent of the maximum fine, and between 10 and 15 per cent of the maxima in the following six decades.

\section{The late-twentieth century reforms}

Reflecting the wave of OSH regulatory reform that swept through Australia from the mid1970s, the Victorian Occupational Health and Safety Act 1985 (OHSA) replaced the traditional style Industrial Safety, Health and Welfare Act 1981 (ISHWA). The OHSA enacted broad general duties on employers (to employees and persons other than employees); selfemployed persons; occupiers of workplaces; designers, erectors and installers of plant; manufacturers, suppliers and importers of plant and substances; and employees. These general duties were 'fleshed out' by regulations and codes of practice that initially simply reproduced the detailed technical machinery guarding and other standards in the old Factories and Shops and Labour and Industry Acts and Regulations. Beginning in 1988, however, regulations and codes generally abandoned technical, detailed, specification standards, and instead used a mix of general duties of care, performance standards (where a goal or target was set, and the duty holder could decide how to meet the target most effectively) and process standards. The last prescribe a process, or series of steps, that must be followed by a duty holder in managing specific hazards, or OSH generally. In the main, they set out hazard identification and risk identification, assessment and control procedures. Part IV of the OHSA also made provision for the election of OSH representatives and the introduction of OSH committees.

The OHSA gave OSH inspectors additional enforcement powers - in the form of improvement and prohibition notices - and made provision for the prosecution of directors and senior managers where a corporate offence against the OHSA was committed with their consent or connivance, or was attributable to their wilful neglect. The maximum penalties for offences were significantly increased to $\mathrm{A} \$ 25,000$ for a corporation, and $\mathrm{A} \$ 5,000$ for an individual. In 
1990, these maxima were increased to $\mathrm{A} \$ 40,000$ and $\mathrm{A} \$ 10,000$ respectively. In 1997 , the maximum fine for contraventions committed by corporations was increased to A $\$ 250,000$ if taken on indictment in the County Court, and $\mathrm{A} \$ 100,000$ if prosecuted summarily in the Magistrates' courts. In addition, under the general sentencing legislation, courts were empowered to adjourn matters once the charges were proved and, without convicting the defendant, required the defendant to be of a recognisance to be of good behaviour, and to fulfil other specified conditions for a specified period. From 1991, courts were also able to impose fines without convicting the defendant. ${ }^{14}$

The general duties, particularly those of employers, appear to be capable of broad interpretation and, in particular, could be interpreted to require courts to examine all aspects of the work process in determining whether an employer has complied with their duties. ${ }^{15}$ Furthermore, the OSH offences differ from 'typical' crimes in that they are 'inchoate' offences, requiring no specific harm to be proven, but rather contemplating the possibility or risk of harm. ${ }^{16}$ These duties are also examples of constitutive regulation, ${ }^{17}$ a form of regulatory law that attempts to use legal norms to constitute structures, procedures and routines which are required to be adopted and internalised by regulated organisations, so that these structures, procedures and routines become part of the normal operating activities of such organisations. Where this fails, the law has the option of intervening more overtly, through external regulation and sanctions (constraining regulation).

In principle, then, the OHSA had the potential to mandate that employers and other duty holders adopt and implement the key principles of effective OSH management, which are generally agreed to include ${ }^{18}$ the integration of OSH management into core management and work activities, the adoption of a systematic approach to OSH management, the ability of the $\mathrm{OSH}$ management system to accommodate change, and valuing worker input to the OSH management system.

\begin{tabular}{|c|c|c|c|c|c|c|}
\multirow{4}{*}{$\begin{array}{c}\text { Table 1 } \\
\begin{array}{c}\text { Enforcement of } \\
\text { the OHSA }\end{array}\end{array}$} & Year & Inspection visits & $\begin{array}{c}\text { Written } \\
\text { observations }\end{array}$ & $\begin{array}{c}\text { Improvement } \\
\text { notices }\end{array}$ & $\begin{array}{c}\text { Prohibition } \\
\text { notices }\end{array}$ & $\begin{array}{c}\text { Cases } \\
\text { prosecuted* }\end{array}$ \\
\cline { 2 - 7 } & $1987 / 88$ & 20,307 & $\mathrm{n} / \mathrm{a}$ & 1,358 & 350 & 45 \\
\cline { 2 - 7 } & $1988 / 89$ & 11,597 & 2,878 & 1,421 & 337 & 42 \\
\hline $1989 / 90$ & 16,331 & 3,177 & 2,375 & 1,034 & 45 \\
\hline $1990 / 91$ & 36,868 & $\mathrm{n} / \mathrm{a}$ & 3,343 & 1,647 & 76 \\
\hline $1991 / 92$ & 45,363 & $\mathrm{n} / \mathrm{a}$ & 3,012 & 1,655 & 119 \\
\hline $1992 / 93$ & 58,746 & 2,777 & 2,851 & 1,004 & 68 \\
\hline $1993 / 94$ & 70,208 & 1,586 & 1,798 & 870 & 64 \\
\hline $1994 / 95$ & 48,374 & $\mathrm{n} / \mathrm{a}$ & 1,481 & 822 & 64 \\
\hline $1995 / 96$ & 44,661 & $\mathrm{n} / \mathrm{a}$ & 2,001 & 975 & 76 \\
\hline $1996 / 97$ & 44,703 & 2,281 & 3,219 & 1,040 & 57 \\
\hline $1997 / 98$ & $\mathrm{n} / \mathrm{a}$ & 2,569 & 3,410 & 1,242 & 84 \\
\hline $1998 / 99$ & $\mathrm{n} / \mathrm{a}$ & $\mathrm{n} / \mathrm{a}$ & 1,735 & 1,059 & 78 \\
\hline
\end{tabular}

\footnotetext{
*These figures include the number of cases brought to court only, not the total number of informations.
} 


\section{Pre-trial processes: the enforcement profile}

The study of OSH enforcement in Victoria from 1983 to 1999 confirms that the contemporary Victorian OSH inspectorate, consistent with all of the other Australian OSH inspectorates, has continued the tradition of enforcement through persuasion, advice and education. Table 1 provides data from the Victorian inspectorate's annual reports in relation to the OHSA. ${ }^{19}$ Only in a small proportion of visits were improvement and prohibition notices issued. Even then, improvement and prohibition notices far outnumbered prosecutions.

This enforcement profile reflected the Victorian OSH inspectorate's 1985 Prosecution guidelines, which were operative until the end of 1997.* The guidelines specified that the 'principal instruments' to ensure compliance with the OHSA were to be improvement and prohibition notices. A failure to comply with a notice would generally lead to prosecution. The guidelines set out six other circumstances in which prosecutions would generally be taken:

- where the alleged breach has resulted in a fatality or 'serious accident'

- the wilful repetition of the same offence

- non-compliance with a provisional improvement notice

- offences in relation to inspectors (section 42)

- discrimination against an employee or prospective employee (section 54)

- 'where the issue of notices is not considered appropriate for ensuring compliance'.

Not only did these guidelines institutionalise the inspectorate's long-standing practice of pursuing an enforcement strategy that made use of prosecution as a last resort, but the focus of the guidelines on prosecution for breaches resulting in fatalities and 'serious accidents' institutionalised the event-focused nature of prosecution. The inspector's attention was immediately drawn away from an examination of the broader context of the event generally the system of work - to focus on the details of the event itself. From 1983 to 1999, 87 per cent of OSH prosecutions conducted in Victoria were the result of an injury or fatality. In the period 1983-1991, only 21 of the 594 cases (under 4 per cent) prosecuted involved a fatality. Most cases prosecuted (67 per cent) involved incidents where fingers or hands were amputated, lacerated or otherwise injured. In the period 1992-1999, just over 20 per cent of cases prosecuted involved fatalities. About 30 per cent of cases involved hand injuries and there were increases in the number of prosecutions for burns ( 6 per cent) and harm from chemical exposure (2 per cent).

In the 1980s, about 90 per cent of cases prosecuted involved injuries or fatalities that took place on machines. Not surprisingly, in about 75 per cent of cases prosecutions were taken under the machinery guarding provisions. In addition, the majority of general duty prosecutions were also machinery guarding cases. The majority of the remainder of cases were prosecutions for failure to report accidents to the inspectorate. This prosecution profile can be accounted for by the fact that, until the 1980s, the inspectorate was predominantly male and was recruited from the manufacturing sector, and the traditional regulatory focus, as noted earlier, had been on dangerous machinery.

In the 1990s, most prosecutions (about 90 per cent) were cases where employers had failed in their general duties to employees. Nevertheless, even after the recruitment of new inspectors - including women and people from a wider range of occupations - and a

\footnotetext{
*New Prosecution guidelines came into operation at the beginning of 1998 but had little impact on this study.
} 
concerted attempt to broaden the range of prosecutions to include non-machinery issues, about 40 per cent of cases up to the end of 1999 involved machinery guarding. The types of prosecution that increased most during the 1990s were cases involving falls, mainly in the construction industry ( 15 per cent), workers being hit by flying objects ( 8 per cent), electrical hazards ( 5 per cent), explosions ( 4 per cent) and exposure to chemicals ( 4 per cent).

Furthermore, 85 per cent of defendants were corporations, the remainder comprising individual proprietors, partners, workers and corporate officers. Despite the possibility of conducting general duty prosecutions in the County Court, in the vast majority of cases the parties chose to have prosecutions heard before a magistrate. Until 1991 there were only two cases where prosecutions were conducted before the County Court. Since then the number has increased marginally, so that in recent years nearly half a dozen cases are conducted each year before the County Court. A couple of cases, including the prosecution of ESSO Pty Ltd in 2001 as a result of a major gas explosion at the ESSO Longford plant, have been prosecuted in the Supreme Court (a superior court). ${ }^{20}$ It should be noted that most defendants plead guilty to OSH offences in the Magistrates' courts. For example, in the period 1990-1998, of the pleas entered, 83 per cent were guilty pleas. In such cases, the matter usually proceeds with the prosecutor giving an event-focused summary of the facts from the bar table.

This prosecution profile suggests that the typical OSH prosecution in Victoria is the result of a serious injury to a male worker, involving inadequately guarded machinery, or a fall from height in construction work. It involves a plea of guilty in proceedings before a magistrate, where evidence of the contraventions is provided through the prosecutor's summary from the bar table of the circumstances surrounding the incident. In the majority of cases, the court finds the charges proved. The central issue, then, is the penalties imposed by the courts.

\section{Sentencing OSH offenders}

\section{The sentencing process}

The Victorian OSH statutes left the courts with a broad discretion to determine the appropriate penalty for an OSH prosecution. The only significant limit was the maximum penalty and the usual sentencing principles developed by the courts. ${ }^{21}$ Given the Anglo-Australian tradition of limiting the role of the prosecutor in the sentencing process to raising the appropriate sentencing principles, and testing sentencing facts raised by defendants, defence counsel tended to control sentencing proceedings. The research shows that the most commonly raised factors were the defendant's safety record, attitude to safety, and co-operation; the role in the accident of the worker or other workers; the suggestion that the inspectorate had overlooked the hazard in a previous visit; that the accident had occurred in unusual or unforeseeable circumstances; and the fact that after the accident the defendant looked after the injured person and/or remedied the hazard. ${ }^{22}$ What De Prez ${ }^{23}$ observes in relation to environmental prosecutions in the $\mathrm{UK}$ is also true of $\mathrm{OSH}$ prosecutions in Victoria, namely that the:

... choice of terminology and style of mitigation surely demonstrates ... what the legal profession and its clients have assumed to be most likely to influence the bench. ... Such arguments are therefore clearly important in analysis of the social construction of these offences, for they are designed to refute and neutralize the criminalisation of the defendant's activities.... The defence, therefore, have the upper hand in being able to reinforce their favoured view of environmental offences. 
In order to assess how successful these strategies were, Table $2^{24}$ outlines the range of sentencing outcomes imposed by magistrates from 1983 to 1999 on defendants once charges under the ISHWA and OHSA had been proved. The table shows the number of informations adjourned without conviction (with the defendant placed upon a recognisance to be of good behaviour and occasionally required to make a payment into the court box or to a charity of the magistrate's choice), the number of 'fines without conviction' (only available to the court after 1992), the number of recorded convictions, and the average fine for offences under ISHWA and OHSA during the period of this study. The table also shows the annual average fine in terms of a percentage of the maximum available fines.

\begin{tabular}{|c|c|c|c|c|c|c|c|}
\hline $\begin{array}{c}\text { Year } \\
\text { and } \\
\text { Act* }\end{array}$ & $\begin{array}{c}\text { Good } \\
\text { behaviour } \\
\text { bond } \\
\text { (GBB) }\end{array}$ & $\begin{array}{c}\text { GBB and } \\
\text { payment } \\
\text { into } \\
\text { court }\end{array}$ & $\begin{array}{c}\text { Fine } \\
\text { without } \\
\text { conviction }\end{array}$ & $\begin{array}{c}\text { Total } \\
\text { convictions }\end{array}$ & $\begin{array}{c}\text { Total } \\
\text { charges } \\
\text { proved }\end{array}$ & $\begin{array}{c}\text { Average } \\
\text { fine } \\
\text { (A\$) }\end{array}$ & $\begin{array}{c}\text { Percentage } \\
\text { of } \\
\text { maximum } \\
\text { fine }\end{array}$ \\
\hline $1983(\mathrm{I})$ & 10 & 3 & - & 66 & 79 & 294.32 & 14.45 \\
\hline $1984(\mathrm{I})$ & 17 & 5 & - & 62 & 84 & 367.58 & 19.19 \\
\hline $1985(\mathrm{I})$ & 10 & 13 & - & 111 & 134 & 426.04 & 21.96 \\
\hline $1986(\mathrm{I})$ & 8 & 1 & - & 90 & 99 & 402.56 & 20.94 \\
\hline $1986(\mathrm{O})$ & 11 & 2 & - & 11 & 24 & $1,368.18$ & 10.27 \\
\hline $1987(\mathrm{I})$ & 2 & - & - & - & 2 & - & - \\
\hline $1987(\mathrm{O})$ & 14 & 11 & - & 56 & 81 & 956.61 & 7.29 \\
\hline $1988(\mathrm{I})$ & - & - & - & 1 & 1 & 500.00 & 25.0 \\
\hline $1988(\mathrm{O})$ & 5 & 1 & - & 43 & 49 & $2,046.00$ & 9.63 \\
\hline $1989(\mathrm{O})$ & 15 & 5 & - & 53 & 73 & $2,181.13$ & 13.28 \\
\hline $1990(\mathrm{O})$ & 2 & 7 & - & 96 & 105 & $2,835.94$ & 22.92 \\
\hline $1991(\mathrm{O})$ & 4 & 3 & - & 147 & 154 & $3,659.86$ & 31.03 \\
\hline $1992(\mathrm{O})$ & 3 & 1 & - & 109 & 113 & $4,248.17$ & 25.5 \\
\hline $1993(\mathrm{O})$ & - & - & 6 & 68 & 74 & $6,037.82$ & 29.0 \\
\hline $1994(\mathrm{O})$ & 4 & 1 & 6 & 75 & 86 & $7,808.41$ & 22.4 \\
\hline $1995(\mathrm{O})$ & 2 & 6 & 10 & 84 & 102 & $6,585.07$ & 19.7 \\
\hline $1996(\mathrm{O})$ & 1 & 3 & 8 & 89 & 101 & $7,793.26$ & 20.9 \\
\hline $1997(\mathrm{O})$ & 1 & 4 & 6 & 88 & 99 & $7,954.56$ & 21.1 \\
\hline $1998(\mathrm{O})$ & - & - & 19 & 73 & 92 & $8,123.29$ & 20.9 \\
\hline $1999(\mathrm{O})$ & 2 & - & 17 & 101 & 120 & $14,673.27$ & 26.7 \\
\hline Total & 111 & 66 & 72 & 1,423 & 1,669 & - & 21.6 \\
\hline
\end{tabular}

Table 2

An overview of sentencing outcomes for informations where the charges were proved: 1983-1999

\footnotetext{
*Prosecutions under the ISHWA are denoted by $(\mathrm{I})$, and under the OHSA by $(\mathrm{O})$.
} 
Table 2 shows that where the charges were proved in prosecutions under the ISHWA and OHSA, a conviction and fine was imposed in relation to 1,423 out of a total of 1,669 charges; that is, in just over 85 per cent of charges. The average fine over the period of the study was just over 21 per cent of the maximum available fine. The percentage of cases resulting in good behaviour bonds from 1983 to 1992 was just over 17 per cent, and over the whole study was 10 per cent. Given that prosecutions were only launched for what the inspectorate considered to be the most serious cases, and that sentencing law stated that good behaviour bonds were not an appropriate form of disposition for offences under the OSH legislation involving serious injury, ${ }^{25-28}$ the number of charges resulting in good behaviour bonds would seem to be remarkably high. If fines without conviction are included in the analysis, the proportion of cases over the entire study where the charges were proved but the defendant was given a disposition that did not involve a conviction was just under 15 per cent. Table 2 indicates that 'fines without conviction' replaced 'good behaviour bonds' as the disposition magistrates preferred to use to express their ambivalence about the true 'criminality' of OSH offences. In the period 1993 to 1999, 'fines without conviction' were imposed in just over 10 per cent of cases where charges were proved.

Clearly magistrates' ambivalence about the criminality of OSH prosecutions influenced their approach to sentencing. But there was far more to the sentencing process than simply an expression of taken-for-granted ideas, or deep-seated ideologies, about corporate crime.

The dynamics of sentencing, and 'pulverisation'

In his study of OSH in the North Sea, Mathiesen ${ }^{29-31}$ notes that 'when lives are lost, fundamental questions concerning the activity ... are often raised [by] conditions which were earlier seen as isolated being placed in relation to each other'; for example, the relationship between the profit motive and the lack of safety measures, or the pace of oil extraction or coal mining. Sociological explanations - focusing on the work process and the organisation of work - raise these concerns in relation to most OSH issues. As Mathiesen notes, when many people perceive such a totality or context, the activity itself begins to be threatened. It then 'becomes important for the representatives of the activity to pulverise the relationships which people begin to see.' An effective method of pulverising revealing relationships is to isolate the event which was the point of departure from the rest of the activity of which the event is part - to 'cut the event out of the fabric in which it exists'. Just as Mathiesen demonstrates that politicians and business people engage in this process in response to macro workplace disasters, so it is argued here that defence counsel in the sentencing process play a similar role in OSH prosecutions.

Three samples (1986-1987, 1990-1991 and 1997-98) of 200 cases prosecuted in Victoria ${ }^{32}$ provide strong evidence that, during OSH prosecutions, the offences and the facts that constitute them are decontextualised or ripped out of the fabric within which they are embedded. Mathiesen describes a number of 'isolation techniques' that can be used to fulfil this purpose, and these have been adapted to show how pulverisation takes place principally in the sentencing process, through arguments raised by defence counsel. ${ }^{33}$

\section{Splintering the event}

The most important isolation technique is to split up or splinter the event. It is isolated from its context by 'splitting or dividing the event into its more or less free-swimming and unrelated bits and pieces'. By splitting up the event, the context within which the event has occurred fades and recedes into the background at the expense of the unrelated questions of detail that are in focus. As demonstrated earlier in this paper, the $\mathrm{OSH}$ prosecution procedures and practices institutionalise this splintering of the event into minor details, because the prosecution 
invariably focuses on a particular incident giving rise to an injury or fatality. For example, in all of the prosecutions in the 1980s involving machinery guarding, the court focused in minute detail on the technical aspects of whether or not there was a guard, how it worked, and the actions of the worker. This in turn facilitated scrutiny of factors that were irrelevant to the offence, such as the injured or deceased worker's behaviour in the events leading up to the incident, a particular malfunction, and the problems faced by the employer at a particular time.

\section{Blame-shifting}

A major consequence of splintering was the close scrutiny of the details of the event, which in turn almost inevitably led to an analysis of culpability based on individualistic notions of causation and the allocation of blame. A number of blame-shifting techniques were used, the most common being to blame the worker. When the author interviewed magistrates about OSH prosecutions in 1988, each indicated that the moral culpability of an employer for an offence would be reduced if there were evidence that the worker had contributed to the accident. This factor was often used in mitigation by defence counsel, despite the fact that the alleged carelessness of the employee has very little to do with the offence of failing to provide a safe workplace.

Another frequently used blame-shifting technique was to direct the blame onto the state - in the guise of the inspectorate. In mitigation, a common factor raised was that the inspectorate had previously inspected the plant without commenting on the hazard under scrutiny. (This argument is deeply rooted in dominant ideologies about the role of the state in the prevention of workplace illness and injury. ${ }^{34}$ ) A third blame-shifting technique argued in mitigation was that the supplier of plant and equipment had, for example, supplied the employer with unsafe equipment and therefore the supplier, not the employer, was responsible for the hazard.

\section{The good corporate citizen}

The most basic and widespread plea in mitigation was that the defendant had an excellent safety record and an exemplary attitude to safety; in effect, portraying the defendant as a 'responsible' company or person. The plea turned the court's attention away from the event itself and away from the organisation of work, to concentrate on the reputation and attitude of the defendant. It was clear that magistrates accepted that the employer's 'good record' (usually meaning that they had no, or very few, previous work-related illnesses or injuries) was an important factor in reducing the defendant's culpability. Most defence counsel in the sampled cases had no difficulty in painting their clients as responsible organisations. Virtually every plea in mitigation involved the defendant claiming a good safety record and a good attitude to safety.

\section{Individualising the event}

As Mathiesen points out, the event may be individualised by making it into 'something unique, something incomparable, something quite special, individual, a-typical.' Such a presentation ensures that far-reaching conclusions or generalisations cannot be drawn from the event, because it is far too exceptional, unique or abnormal. For example, workplace injuries can be typified as 'freak accidents', 'catastrophes' or 'tragedies', signifying that the event is something unusual and unexpected because, in the words of Mathiesen, 'if one all the time had to expect tragedies, the activity as a whole ... would ... not be initiated in the first place.' Furthermore, if an event is unusual, both the severity of the contravention and the culpability of the defendant must be reduced. Hence, there is less need for the sentencing court to be concerned with punishment, rehabilitation or deterrence. This plea was routinely built onto a 'good corporate citizen' plea to emphasise the unusual nature of the incident giving rise to prosecution. In other words, the defendant tried to show that usually it had an unblemished approach to 
OSH, but that on this particular occasion the exceptional had occurred. An important aspect of the technique was that there be a highly detailed scrutiny of the event, without any reference to a systematic management approach to OSH. This enabled defence counsel to argue that the exact circumstances of the event were unforeseeable.

In Victoria, a classic example of this isolation technique was used in the $R-v$-Simsmetal Ltd 1989 prosecution in the Victorian County Court. ${ }^{35}$ The charges arose out of an incident in which one of the company's furnaces exploded, killing four workers and severely injuring another seven. The explosion occurred because the company's chemical handling procedures were so defective that sodium nitrate was stored in unlabelled bags in a shed in which potassium chloride was usually stored. A forklift driver transported the sodium nitrate to the smelter, believing it to be potassium chloride - an accepted and safe fluxing agent. The court, in sentencing, referred to the storage of sodium nitrate in the shed as 'evil chance' and the mix up as the 'intervention of malevolent chance'. The explosion was portrayed as being the result of bad luck, rather than the inevitable consequence of bad work procedures and practices.

\section{Isolating the present from the past and future}

Mathiesen argues that to form a total or overall understanding of an event, it is important to perceive the past, present and future of the event. A total perspective is avoided by isolating these three aspects from each other. The previous isolation techniques illustrate how this is done - if the event is split up, the past and contextual present are removed from the analysis. If the event is individualised, the event's past is replaced by the mythical past contained in the 'good record' and 'good attitude'.

In sentencing pleas, defence counsel regularly isolated the event in the present, and arguably reconstructed 'the present' to make it appear benign, even heroic. For example, maximum emphasis was often placed on the human or humanitarian aspects of the case in the present, by asserting that the employer was looking after the injured worker. In the sampled cases, examples ranged from taking the worker to hospital after the injury, visiting the worker in hospital, re-employing the worker afterward, assisting with the worker's rehabilitation and so on. In virtually every case, a key factor in mitigation was that, after the incident and before the prosecution proceedings, the employer had rectified the situation; for example, the employer had guarded the machine as required by the inspectorate. As one magistrate commented in an interview: 'the courts have to give credit to people who have done the right thing.'

Another isolation technique involved separating the event from its context by relegating it more or less to an outmoded past. This mitigating technique was used in most cases and was usually accepted by the court. Examples include assertions that, since the 'accident', the company had replaced the offending machine, engaged a new management team, employed an $\mathrm{OSH}$ consultant or introduced a new OSH programme. The suggestion here is that the previous work method was old fashioned. Consequently, by relegating the event to an outmoded past, it was made untransferable to other parts of the work process.

\section{Anthropomorphising the defendant}

Even though some defendants relied heavily on the corporate veil to reduce the impact of prior convictions on the assessment of penalty in the particular case, in many other cases a tactic used by the defendant was to fuse the characteristics of the personnel running the corporation with the corporation itself, so that the corporate defendant could gain the exculpating benefit of the admirable human characteristics of its management or directorship. On other occasions, defence counsel gave the corporation human characteristics and qualities, to ensure that the 
fictional corporate entity received the benefits of a sentencing system that had developed around an assessment of the character of the human defendant. For example, defence counsel were sometimes careful to ensure that the court was aware of the defendant corporation's role in the community - its charitable works and so on. On other occasions, the awards received by personnel within the corporation were attributed to the corporation. Sometimes the fact that the managing director was hard working and concerned for the welfare of workers was raised as a factor.

\section{Countering the isolation techniques}

These, then, are the isolation techniques used by defence counsel to transform and individualise the already decontextualised event in the sentencing process. Victorian OSH prosecutors gradually developed strategies to counter these arguments, but were never able to prevent fully the transformation of the issues.

One strategy was for the prosecutor to play a greater role in sentencing, primarily by ensuring that their summaries from the bar table outlined defects in the overall system of work, and provided as much context as possible. Prosecutors also made greater use of their right to challenge the submissions put to the court by the defendant, and to emphasise the sentencing principles that had been developed by the courts. To support this strategy, the inspectorate sought to ensure that inspectors collected relevant sentencing material (such as evidence of contraventions discovered - and action taken - in previous visits, and the defendant's accident record) during their investigations. There was also much evidence that as the OSH inspectorate's competence in investigation improved during the 1990s, the sentencing outcomes improved. In addition, it was clear that, over time, magistrates became hardened to the mitigating factors raised by defendants, particularly the blame-shifting arguments and unsubstantiated assertions of good corporate citizenship.

Another possible strategy was for prosecutors to appeal against sentencing decisions of magistrates when these resulted in inadequate penalties. An analysis of OSH sentencing decisions taken on appeal from the Magistrates' courts to the intermediate level County Court revealed that, during the 1980 s, the few appeals that were conducted were initiated by the defendant. ${ }^{36}$ In the early 1990s, two appeals were initiated by the prosecutor. One resulted in a marginal increase in fine; in the other, the County Court refused to increase the fine. From 1993 to 1999 , there were 28 appeals to the County Court -18 by a defendant and 10 by the prosecution. Of the 18 appeals brought by defendants, four were abandoned, 11 resulted in a reduction of penalty, and in three cases the County Court affirmed the penalty imposed by the magistrate. Of the 10 appeals by the prosecutor, in one case the court affirmed the penalty imposed by the magistrate. Six of the cases resulted in the County Court setting aside a fine without conviction, and convicting and fining the defendant. In the other three cases, fines were increased from $\mathrm{A} \$ 5,000$ to $\mathrm{A} \$ 20,000, \mathrm{~A} \$ 20,000$ to $\mathrm{A} \$ 27,000$, and $\mathrm{A} \$ 5,000$ to $\mathrm{A} \$ 7,000$. It appears, therefore, that the appellate procedures have been used more frequently by defendants than prosecutors. The prosecution tended to use the appeal process mainly to overturn decisions by magistrates to impose a fine without imposing a conviction.

The other function of the County Court was to develop sentencing principles, which it did in its role as an appeal court, and also when hearing prosecutions at the first instance. As shown below, these sentencing principles did not challenge the isolation techniques.

The first County Court case to establish sentencing principles for OSH prosecutions was $R-v$ Simsmetal Ltd $1989 .{ }^{35}$ The court stated that: 
... the aspect of deterrence, even if it is thought in this context somewhat artificial, is the one most likely to promote and enhance the raison d'etre for the legislation. ${ }^{35,37}$

The maximum penalties, however, were traditionally reserved for the worst offenders, that is to say:

... those who behave with deliberate, wilful or reckless disregard for the safety of others, and for those whose conduct had in the past attracted prior convictions and punishment, and who were still offending nevertheless. ${ }^{35}$

This principle is interesting because, despite the fact that the OSH offences are absolute or strict liability offences qualified by 'practicability', for penalties to approach the maxima some mens rea in a traditional sense was required. ${ }^{38}$ The court stated that it had to balance the factors raised by counsel to determine the penalty, which included many of the traditional isolation techniques (in this case the 'good corporate citizen', 'individualisation' and 'isolation in the present' techniques). The court acknowledged the difficulty of trying to balance up these factors, a task made even more difficult by the fact that the defendant was a corporation. ${ }^{35}$

Finally, the court noted that guilty pleas 'which reflect the concern and dismay of those who guide the affairs of the company at the occurrence of the disaster, and which exhibit an appropriate reaction to it', are a factor in mitigation of sentence.

As the Simsmetal case shows, the courts since 1989 have been careful to stress that the OSH offences are serious criminal offences. ${ }^{39,40}$ At the same time, some judges have been mindful of the differences between OSH crime and other criminal offences. For example, in Singleton (VWA) - $v$-Fletcher Construction Australia Ltd 1989, ${ }^{41}$ Judge Rizkalla remarked that the OHSA's:

... emphasis on prevention, and the role of enforcement procedures in securing prevention, does distinguish the sentencing process in these matters, from those in the ordinary criminal jurisdiction.

Yet apart from these occasional statements that recognise the atypical elements of OSH offences when compared to traditional criminal offences ${ }^{42}$ the sentencing principles stated by the courts in OSH cases appear simply to apply normal sentencing principles without a coherent attempt to address the special features of OSH crime, particularly the constitutive and inchoate nature of the OSH duties, as described earlier in this paper.

The Victorian courts emphasise that the penalty for OSH offences must reflect the gravity of the offence, ${ }^{43}$ what the New South Wales Industrial Relations Commission describes as the 'objective factor' in sentencing. ${ }^{44}$ Importantly, during the 1990s, the courts began to emphasise that, in sentencing OSH offenders, they had to have regard to the nature of the breach rather than the consequences of that breach. This principle has been most clearly stated in DPP - $v$ Ancon Travel Towers Pty Ltd $1998,{ }^{37}$ where Judge Mullaly stated that:

Offences under the [OHSA] are not defined in terms of consequential injury or death, but rather in terms of a failure to fulfil a positive duty under the Act. Thus, the seriousness of an offence under the Act is not determined by the result of the offence but by the seriousness of the failure to take measures that might reduce or eliminate the risk of accidents occurring and the injuries that flow therefrom. Nonetheless, the degree of the risk 
of injury or death arising from the unsafe system of work is relevant. The fact that there is great inherent danger in a system or course adopted is an aggravating factor. Regard may be had, in assessing the seriousness of the failure of the Act, to the consequences of the offence where injury or death result.

Nevertheless, as cases like Simsmetal and Ancon show, when assessing the seriousness of the breach, the courts take into account the fact of death or injury as indicating the gravity of the breach. Consequently, Victorian courts have taken into account victim impact statements when assessing penalties for OSH breaches ${ }^{45}$ Furthermore, the Supreme Court in $R-v-A C$ Hatrick Chemicals Pty Ltd \& Ors $1995^{45}$ held that the fact that proven breaches of the OHSA did not cause the death or serious injury resulting from the incident tended to reduce the level of penalty.

This analysis suggests that the sentencing principles developed by the appellate courts, particularly the County Court, appear not to have restricted the use of most of the isolation techniques. The County Court, for example, has stated that the unusualness of a task - in the sense that it was not anticipated - does not exculpate the defendant, but it is a matter which can be taken into account when determining penalty. ${ }^{39,46}$

The County Court has outlined principles limiting blame-shifting. ${ }^{47}$ It has held that where an employer has breached its obligations under the OHSA, 'the fact that the responsibility was spread over other persons does not ... significantly alter the position so far as concerns the responsibility' of the defendant company. ${ }^{48}$ In Singleton (VWA) $-v$-Fletcher Construction Australia Ltd 1999, ${ }^{41}$ Judge Rizkalla rejected any suggestion by the defendant that the possibility that other persons should have been charged over the incident could have a direct bearing on the penalty imposed on the offender before the court. Likewise, in DPP - $v$ - Pacific Dunlop Ltd 1994, ${ }^{43}$ Judge Mullaly stated that the worker's familiarity with the machine was not relevant in determining the seriousness of the offence or the severity of the sentence, because the legislation was designed to protect those for whom familiarity breeds a cavalier attitude. ${ }^{39}$ Yet blame-shifting in a more subtle form has been institutionalised in Stratton - $v$ Bestaburgh Pty Ltd 1994, ${ }^{50}$ where the Supreme Court indicated that it favoured a lesser penalty when the person injured is an independent contractor who has more control over the work than an employee. Similarly, in $R-v$-Granowksi $1996,{ }^{46,47}$ in imposing the fine the court took into account the fact that the unsafe work was undertaken by a skilled tradesperson. ${ }^{51}$

The County Court has established clearly that the defendant's good OSH history and the absence of prior convictions (what the New South Wales courts refer to as 'subjective factors' $)^{44}$ will reduce the level of fine. ${ }^{37,40}$ Victorian case law shows that the courts have looked to a number of factors in assessing the character of an organisation in relation to OSH. The factors include ${ }^{52}$ the length of time the organisation had been in operation; the manner in which the organisation has responded to past OSH incidents; the history and extent of the organisation's co-operation with employees in relation to $\mathrm{OSH}$, and with the $\mathrm{OSH}$ inspectorate; the level of care (or lack of concern) the organisation shows to its workers; whether the defendant puts profits ahead of worker safety; and whether there is a wilful neglect of employee safety. A failure to take remedial action after a prior incident of a similar nature leading to injury or death will constitute an aggravating factor. Likewise, the gravity of an offence will be illustrated where a simple procedure with minimal cost would have prevented the incident. As the County Court illustrated in $R-v$ - Natra $1995,{ }^{53}$ the ease of measures to avoid repetition of the incident can indicate the gravity of the offence. 
In $R$ - v-Simsmetal $1989,{ }^{35} R-v$-Natra $1995^{53}$ and $R-v$ - Granowski $1996,{ }^{46}$ the County Court made it clear that the courts could regard as a mitigating factor the remedial steps taken by the defendant subsequent to the incident to ensure a safe and healthy working environment. ${ }^{54}$

In $R-v$-Simsmetal $1989,{ }^{35}$ the court expressly stated that the highest penalties were to be reserved for those with criminal records. In $R-v$-Civil and Civic Pty Ltd 1992, ${ }^{38}$ however, Judge Crossley, while affirming the sentencing principles in the Simsmetal case, stated a new principle, namely that in imposing a fine the court should bear in mind the provisions of section 53 of the OHSA, which provides 'different maximum penalties for different levels of criminal history'. That is, the fact of no prior convictions has been taken into account by the legislature in fixing the maximum penalty of $A \$ 25,000 .^{36,55,56}$

Thus, the severity of a sentence will be greater where the defendant has prior convictions under the OHSA, especially when the convictions relate to incidents of a similar nature to the immediate offence. ${ }^{45}$

These cases suggest that while it is clear that, since the late 1980s, the courts have developed a number of principles in sentencing OSH offenders, these principles have been extremely broad, have been based on general sentencing principles, and have not countered most of the isolation techniques outlined earlier in this paper. Some, indeed, have reinforced the isolation techniques. To a large extent the sentencing principles merely reiterate the rhetoric that OSH offences should be taken seriously, while failing to counter the very process that ensures that they are not taken seriously - the accumulative use of the various isolation techniques by defence counsel to mitigate the culpability of OSH offenders. It may be, however, that the New South Wales Industrial Relations Commission's decisions on sentencing, which are largely consistent with the Victorian decisions, and which leave most of the isolation techniques unchallenged, at least recognise the potential of the 'subjective' factors to undermine the integrity of the OSH sentencing process. The leading cases emphasise that the 'objective' sentencing factors are more important than the 'subjective' factors, so that the court must ensure 'that the allowance for subjective factors does not produce a sentence which fails to take into account the objective gravity of the offence. ${ }^{44}$

Despite these important strategies developed by prosecutors to try to prevent the operation of the isolation techniques, it is clear that the isolation techniques were difficult to counter. Consequently, OSH prosecution proceedings inevitably failed to connect the event under scrutiny to the totality of which it was part. This is not to deny that prosecution plays a crucially important part in the enforcement of OSH statutes ${ }^{57}$ or that, over time, OSH fines increased dramatically in Victoria (see Table 2). Indeed, as new post-1997 maximum penalties took effect, in 2000 and 2001 the maximum penalties imposed by the courts continued to rise significantly, ${ }^{58,59}$ and there was much anecdotal evidence that increased fines were having a deterrent effect and motivating at least some employers to rethink their attitudes and approaches to OSH. Rather, the point here is that the individualistic form of the criminal law not only reduced the level of actual fines imposed when compared to the maxima available, but also played an important role in sanitising OSH offences. The remainder of this paper develops this argument.

\section{The form of the criminal law}

The ISHWA and OHSA were criminal statutes grafted onto the existing rules pertaining to criminal procedure and sentencing. They were principally concerned with the mechanics and details of standard-setting, the establishment of the inspectorate and, in the case of the OHSA, 
the functions and powers of OSH committees and representatives. Apart from the penalty structures in the Acts, all other provisions governing the procedural and sentencing aspects of prosecutions were contained in the statutory and common law provisions in the mainstream criminal law. There are a number of consequences arising from an unchallenged adoption by $\mathrm{OSH}$ regimes of the processes and procedures of the mainstream criminal justice system.

The event-focused nature of the criminal justice system

The large majority of prosecutions within the criminal justice system are event focused whether they be traffic offences, theft, burglary, possession of illegal drugs, domestic violence, assault, sexual assault, murder or any other of the many statutory or common law offences. The rules of criminal procedure have evolved around, and consequently institutionalised, this event-focused nature of criminal procedure. As argued earlier in this paper, OSH offences differ from most criminal law offences in that they are both constitutive and inchoate. In OSH crime the actual injury is a consequence of a work process that has not been organised, structured and monitored so as to ensure that it is safe and without risks to health. At a deeper level, the issue is the control of the work process by the employer to the detriment of the employee, the prevalence of other organisational objectives (such as short term or long term profitability, increased market share, productivity, increased utilisation of capital, longer production runs and so on) over OSH objectives, and the failure to practise systematic OSH management.

As this paper has demonstrated, despite the inchoate and constitutive nature of $\mathrm{OSH}$ standards, OSH prosecutions invariably focus on events. It is far easier for the prosecution to prove that the facts constituting an event are in breach of the statutory provisions than it is to prove that management has failed to organise work so that it is safe and without health risks for workers, or even that a system of work is inherently hazardous, regardless of whether or not ill health has resulted. The important point is that this bias towards events and incidents is a direct result of the form of the criminal law, in particular the rules of evidence and procedure, and the fact that most criminal prosecutions are event focused. The legal form, deeply rooted in individualistic notions of responsibility, is preoccupied with events and details, and with scrutinising individual actions. As Hale ${ }^{1}$ notes:

There is, therefore, an institutionalised drift towards constructing OSH issues by focusing on the detailed actions of the actors during the event, rather than focusing on the overall system of work surrounding the event, or the underlying organisation of work at the workplace.

\section{The nature of the trial}

The criminal trial in an adversarial legal system has the 'effect of abstracting the legally relevant "facts" from their complex social reality, thereby depoliticising the issue before the court. ${ }^{90}$ McBarnet ${ }^{61}$ notes that:

... the facts of a case - a case of any sort - are not all the elements of the event, but the information allowed in by the rules, presented by the witnesses, and surviving the credibility test of cross-examination.

Not only is the law event focused, but its view of the event is partial. This partial focus is endemic to law. The adversarial nature of the trial emphasises a legally constructed contest between the prosecutor's and defence counsel's version of reality, with little room for the experience of the victim (or indeed the collective issues facing workers), whose interests, different from those of the prosecutor, are marginalised. ${ }^{62}$ Even with the introduction of 
provisions for 'victim impact statements' in 1994, the victim's interests are simply represented in terms of pain and suffering, rather than more broadly as a participant in workplace processes. As a result the case is depoliticised, so that the parties are unable to show the social, economic or political issues underlying the act in question. This characteristic of abstracting 'the facts of the case' from the social, economic and political context is basic to the form of the criminal law used in contemporary Australia. Law, as Hunt observes, plays an important ideological role in individualising and decontextualising the experience of social relations under capitalism..$^{63}$ Not only are issues decontextualised, but they are then recontextualised:

... in terms recognizable to the legal gaze, ... into the form of an individual moral actor for the purpose of fitting the corporate persona into the discourse of criminal law conceptions of responsibility and sanctioning. ${ }^{62}$

It was demonstrated earlier how the investigation and prosecution of OSH offences have transformed OSH issues into 'terms recognizable to the legal gaze'. Not only is the prosecution process event focused and abstracted or decontextualised, but the sentencing process is extremely open-textured, with very little constraint on the discretion exercised by the court in the sentencing process. There is a significant tension in the legal form between the open texture of the rules of sentencing and the magistracy's need to particularise the sentence to the facts of the case at hand. This enables both defence counsel and the court to enunciate the rhetoric of the importance of OSH and deterrence, but at the same time chip away at the defendant's liability by transforming the nature of the issue until it is more in line with individualistic notions of culpability implied in the criminal law. The result is a divergence or gap $^{64}$ between the rhetoric of the seriousness of OSH and the importance of deterrence, and the individual case-based reality of the process of decontextualisation and individualisation, without undermining the value of the rhetoric as ideology.

The individualistic criminal law, business organisations, and the ideological role of mens rea A further characteristic of the form of the criminal law is that it has developed over the centuries in the context of crime committed by individuals. But most defendants in $\mathrm{OSH}$ prosecutions are corporations. However, the criminal justice system has assimilated business organisations by regarding them as individual moral actors - in the same way as it deals with natural persons - rather than attempting to adapt the legal system to accommodate the collective nature of organisational behaviour. It has applied the normal sanctions to corporations where appropriate (eg fines), has discarded others considered to be inappropriate for corporations (eg imprisonment), but has failed to explore new forms of sanctioning.

The abstracted, event-focused and individualistic nature of the criminal law contributes towards another characteristic of the criminal law - its emphasis on traditional notions of mens rea as the central component of criminal liability. It certainly makes some sense for a criminal justice system focusing on events perpetrated by individuals to focus on an individualistic notion of culpability, having at its core the intention, in a broad sense, to perpetrate the event in contravention of the law. But it does not make sense to transfer these notions to OSH crimes, where strict liability can be justified because illness and injury is an inevitable consequence of work systems organised in a manner that does not take into account OSH considerations.

Sargent ${ }^{60,65}$ has argued that the notion of mens rea is important on the level of rhetoric in that it legitimises and reinforces the individualistic distinction between 'real crimes', based on the 
violation of accepted social values, and mere regulatory or public welfare offences, which are seen as morally opprobrious. This perpetuates the relative immunity of corporate offenders, as argued earlier in the paper with reference to Carson's work. ${ }^{66}$

On another level, the strict or absolute provisions coupled with the notion of practicability in the OHSA's general duty provisions limit the prosecutor to having to prove fault as negligence without having to demonstrate full criminal intention or recklessness in traditional criminal law thinking. The relative brevity of the prosecution's summary in uncontested cases further limits the prosecutor's ability to highlight the defendant's culpability. At the same time, the broad sentencing discretion given to the court invites defence counsel to mitigate strongly by suggesting that fault is absent, or at least minimal. As demonstrated earlier in the paper, sentencing procedure and practice strongly support defence counsel's efforts to reconstruct the offence so as to minimise culpability.

In her study of environmental prosecutions, De Prez ${ }^{23,67}$ observes that the strict liability provisions in environmental regulation:

... act as a cloak for many defendants, for as the prosecutor is not required to prove 'fault', this leaves defence counsel plenty of room to deny culpability in order to attract the sympathy of the bench.

This neutralising of the culpability of OSH offenders must be seen in the context of the discretion to prosecute. In most cases, prosecutions are taken because the matters represent more serious contraventions, where the defendant has demonstrated clear moral culpability. ${ }^{68,69}$ The prosecution process itself systematically denies that seriousness. ${ }^{67}$ Yet it is difficult for the prosecution to reproduce before the court the factors that may have led the inspector to construct moral blameworthiness.

The form of the criminal law enables defence counsel to reproduce individualist arguments about criminal liability, and to transform issues of culpability from the systematic focus - so important in the nature of OSH - to an event-focused 'every case is decided on its facts' approach, with factors weighed up against each other. These factors, together with the open texture of sentencing procedure, facilitates, indeed institutionalises, an approach in which culpability can be decontextualised, transformed and individualised.

\section{Trivialising $\mathrm{OSH}$}

The problems raised for the regulation of OSH offences by the individualistic, event-focused form of the criminal law are exacerbated by the venue of the vast majority of OSH

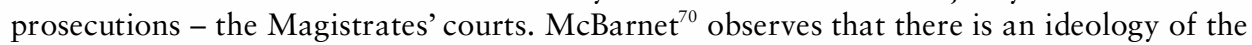
'triviality' of the matters coming before the Magistrates' courts, which are seen to deal with 'trivial' everyday matters, with low penalties and little public scrutiny. The Magistrates' courts are at the lowest level of the judicial hierarchy and traditionally they adjudicated 'petty crime'. Within this setting, the question arises as to how magistrates can fail to individualise OSH offences and regard them as not being at the upper level of egregiousness. Not only are the Magistrates' courts geared towards fast summary justice, but the emphasis on guilty pleas, and the fact that most cases are indeed guilty pleas, institutionalises an analysis of culpability that is primarily based on magistrates' common sense opinions of $\mathrm{OSH}$, and the briefly constructed facts put to the court by the prosecutor and reinterpreted by defence counsel. Most important of all, magistrates are not accustomed to imposing large penalties on corporations. Most offences prosecuted in the Magistrates' courts have maxima below those in the OHSA, and 
most of their penalties are imposed on individuals with a low capacity to pay. The defence strategy of transforming, decontextualising and individualising the issues was aimed at trivialising the charges. The setting of the prosecutions, in the Magistrates' courts, ensured that the triviality of the offences was always an issue, and a continual matter for contest.

\section{The implications of decontextualisation and individualisation}

All these factors explain why fines for OSH offences tend to be low, and thus are not a serious punishment or deterrent to employers. Magistrates tailor the sentence to the culpability of the defendant. They have difficulty conceiving these offences to be truly criminal, are susceptible to 'careless worker' and other blame-shifting arguments, and the key isolation techniques operate to reduce their perception of the defendant's blameworthiness.

On another level, this study suggests that even though the OSH legislation has the potential to enforce a broad construction of OSH issues, the models of injury causation and OSH management reproduced by the prosecution process are very narrow. This has important implications for the use of the criminal law in stigmatising dangerous workplace structures. If prosecution is to have the desired impact of improving working conditions, it must be clear to employers that they need to organise the work process differently to avoid legal liability. There needs to be an emphasis on developing an organisational culture and ongoing organisational processes that envisage OSH as an interdisciplinary and broad, systems-based management activity. ${ }^{18,71}$ It is not sufficient, therefore, merely to change the rhetoric of the law and the content of the substantive legal rules in order to optimise the law's role in preventing workplace illness and injury through criminal regulation. The form of the criminal law used needs to be examined, and transformed, to ensure that the desired approach is constructed at all stages of the process. ${ }^{72}$

Finally, the OSH prosecution process may, indeed, defuse OSH as an issue. The conflictual nature of work relations is obscured by the decontextualised and individualised nature of the trial, which provides no scope to link particular hazards with the nature of capitalist work relations. The individualistic form of the criminal law effectively decriminalises OSH and prevents the criminal justice system from treating equally all forms of socially deviant behaviour. The criminal law and concepts of sentencing are not empty vessels that can be filled with whatever content society chooses. In OSH offences not only do the elements of the offence decontextualise issues of OSH to the benefit of the defendant, but the sentencing process further transforms and individualises the offence, and enables the culpability of the defendant to be further sanitised.

At the deepest level, then, the courts' reconstructions of OSH issues play an important role in defusing $\mathrm{OSH}$ as a social, political and industrial issue. The state is heavily dependent on the process of the private accumulation of capital, and must create and sustain the conditions of accumulation..$^{73,74}$ The state must not simply be seen as an instrument acting on behalf of the dominant capitalist classes. Its legitimacy depends on it at least giving the appearance of transcending the interests of particular capitalists. It also has to respond to pressures 'from below' to maintain the social conditions necessary for capitalist accumulation. Recent critical legal theory has attempted to explain the consensual nature of law, in particular the manner in which it functions to reproduce ideologies supporting capitalist and patriarchal relations of production. ${ }^{75,76}$ This in turn has led to a greater examination of the role of law as an institutional site for the production and dissemination of ideologies that reproduce consent for unequal relations within capitalism. Ideologies play 
a role in defining the way in which social relations are lived and experienced, and in the manner in which political and social conflicts are identified and resolved. ${ }^{63,77}$ As Carson \& Hennenberg ${ }^{34}$ note:

Workplace fatalities, injuries and disease are potentially disruptive of the social order and to the ongoing process of capital accumulation.

The fact that such disruptions have not occurred is due in some measure to the ideological role played by OSH legislation. ${ }^{34}$ Central to these ideologies is the ambiguity and conventionalisation of OSH crime and the fundamental acceptance that $\mathrm{OSH}$ is the responsibility of the state. These ideologies are reinforced by dominant workplace ideologies based on the acceptance of the overriding importance of private property; the belief that workplace illness and injury are an inevitable by-product of industrial progress and the technological imperative, and therefore beyond human control; the stereotype of the 'careless worker'; and workplace ideologies stemming from a unitary view of workplace relations.

The evidence in this study suggests that the courts themselves play an important role in reproducing consent for key conceptions of $\mathrm{OSH}$, and a narrow model of injury causation. The key 'taken-for-granted' ideas or ideologies discussed above have permeated proceedings before the courts and have severely restricted the courts' examination of OSH issues. The ideologies work in two closely related dimensions. At one level, the key legal actors - the inspectors, prosecutors and especially defence counsel and the magistracy - are informed by these ideologies, which have their origins outside the law but become an integral part of legal proceedings, legislation and legal doctrine so that they become virtually unquestioned. On another level, as argued earlier, the form of law itself plays a crucial role in decontextualising and individualising the experience of social relations under capitalism. Once the OSH issue is isolated as a disembodied event and recontextualised - within the notion of the defendant's good corporate citizenship and the dominant ideologies of the 'careless worker', the 'inevitability of accidents' and the 'central responsibility of the inspectorate to discover hazards' - the court's understanding of the incident is transformed and individualised, and its perception of the defendant's liability is severely reduced. The court, therefore, becomes an important site in which meanings of the social world are constructed, contested and disseminated. ${ }^{62,77}$

The isolation techniques discussed earlier enable the courts to play a role in repairing threats to the 'fragile edifice of consent'. The focus of the prosecution on a particular employer and a particular event suggests that what the court is dealing with are isolated instances of unsafe work practices in an otherwise safe industrial world, rather than an example of a more deepseated problem concerning the priorities given to the provision and maintenance of working environments that are safe and without risks to health. The court is seen to be dealing with the issue, and convicting offenders, but at the same time sanitising the issues so that the underlying activity - the production of goods and services - is not threatened.

\section{Conclusion}

This paper has argued that the ill-fit between corporate OSH offences and the mainstream criminal justice system has undermined the potential effectiveness of OSH prosecutions. While some may argue that the paper illustrates the futility of OSH prosecutions, ${ }^{78}$ that is not the intention. Rather, the paper demonstrates the need for OSH regulators to reconstruct criminal law and procedure surrounding OSH prosecutions so that such offences are redefined as 'real crimes' and the processes of individualising and decontextualising OSH offences are reversed. ${ }^{79,80}$ 


\section{References}

1. Hale A. Introduction: the goals of event analysis. In: Hale A, Wilpert B and Freitag M (eds). After the event: from accident to organisational learning. Oxford: Pergamon, Elsevier Science, 1997: 6-8.

2. Johnstone R. Occupational health and safety prosecutions in Victoria: an historical study. Australian Journal of Labour Law 2000; 13 (2): 113.

3. Gunningham N, Johnstone R and Rozen P. Enforcement measures for occupational health and safety in New South Wales: issues and options. Sydney: WorkCover New South Wales, 1996: appendix.

4. Law Commission. Codification of the criminal law: strict liability and the enforcement of the Factories Act 1961. Published working paper no. 30. London: Law Commission, 1970.

5. See also Johnstone R. Occupational safety, courts and crime: the legal construction of occupational health and safety offences in Victoria. Sydney: Federation Press: chapter 1.

6. McBarnet D. Magistrates' courts and the ideology of justice. British Journal of Law and Society 1981; 8: 181-197.

7. Hawkins K. On legal decision-making. Washington and Lee Law Review 1986; 43: 1161-1179.

8. Johnstone R. Occupational health and safety law and policy. Sydney: LBC Information Services, 1997: chapter 3.

9. Johnstone R. Occupational health and safety law and policy. Sydney: LBC Information Services, 1997: chapter 2.

10. Carson W G. The conventionalisation of early factory crime. International Journal of the Sociology of Law 1979; 7: 37-60.

11. Carson W G. The institutionalization of ambiguity: early British Factory Acts. In: Geis G and Stotland E (eds). White collar crime: theory and research. London: Sage, 1980.

12. Glasbeek H. The maiming and killing of workers: the one sided nature of risk taking in capitalism. Ottawa: Carleton University, Department of Law, 1986.

13. Tucker E. Administering danger in the workplace: the law and politics of occupational health and safety regulation in Ontario, 1850-1914. Toronto: University of Toronto Press, 1990.

14. Sentencing Act 1991 (Vic) ss 7(f) and 8.

15. Johnstone R. Paradigm crossed? The statutory occupational health and safety obligations of business undertakings. Australian Journal of Labour Law 1999; 12 (2): 73-112.

16. $R$-v-Australian Char Pty Ltd [1996] 64 IR 387: 400.

17. Hutter B M. Regulation and risk: occupational health and safety on the railways. Oxford: Oxford University Press, 2001.

18. Frick K, Jensen P L, Quinlan M and Wilthagen A (eds). Systematic occupational health and safety management - perspectives on an international development. Amsterdam: Elsevier Science Ltd, 2000.

19. Johnstone R. Occupational safety, courts and crime: the legal construction of occupational health and safety offences in Victoria. Sydney: Federation Press: 90.

20. DPP -v-ESSO Australia Pty Ltd [2001] 107 IR 285.

21. Fox R G and Freiberg A. Sentencing: state and federal law in Victoria. 2nd edition. Melbourne: Oxford University Press, 1999.

22. Johnstone R. Occupational safety, courts and crime: the legal construction of occupational health and safety offences in Victoria. Sydney: Federation Press: 180-184.

23. De Prez P. Excuses, excuses: the ritual trivialisation of environmental prosecutions. Journal of Environmental Law 2000; 12 (1): 65-78.

24. Johnstone R. Occupational safety, courts and crime: the legal construction of occupational health and safety offences in Victoria. Sydney: Federation Press: 202. 
25. Curtis -v-Email Ltd [1970] 12 AILR 194.

26. Tucker - $v$ - Mappin [1983], unreported, Industrial Relations Commission of Victoria in Court Session (Marshall P), case no. 91/1983, 21 November.

27. DPP - v-Pacific Dunlop Tyres Pty Ltd and Goodyear Tyres Pty Ltd, trading as South Pacific Tyres [1991], unreported, County Court of Victoria (Fricke J), 22 November.

28. For New South Wales cases, see Thompson W. Understanding New South Wales occupational health and safety legislation. 3rd edition. Sydney: CCH, 2001: 88-89.

29. Mathiesen T. Kunsten å isolere en ulykke' (translated as 'The art of isolating an accident'). In: Eggen B and Gundersen H (eds). Nordsjøtragedien (translated as 'The North Sea tragedy'). Oslo: Pax Publishers, 1980: 187-202.

30. Mathiesen T. Disciplining through pulverization. In: Mathiesen T. The hidden disciplining: essays on political control. Oslo: the author, 1981.

31. Mathiesen T. Die lautlose disziplinierung (translated as 'The hidden disciplining'). Bielefeld; AJZ Verlag, 1985. I have benefited from an English translation by the author of this work.

32. Johnstone R. Occupational safety, courts and crime: the legal construction of occupational health and safety offences in Victoria. Sydney: Federation Press: chapter 7.

33. Readers seeking more detailed examples of these techniques should consult Johnstone R. Occupational safety, courts and crime: the legal construction of occupational health and safety offences in Victoria. Sydney: Federation Press: chapter 7.

34. Carson W G and Henenberg C. The political economy of legislative change: making sense of Victoria's new occupational health and safety legislation. Law in Context 1988; 6 (2): 1-19.

35. $\quad$ - $-v$-Simsmetal Ltd [1989], unreported, County Court of Victoria (Villeneuve-Smith J), Melbourne, 9 March.

36. Johnstone R. Occupational safety, courts and crime: the legal construction of occupational health and safety offences in Victoria. Sydney: Federation Press: chapter 8.

37. See also DPP - v-Ancon Travel Towers Pty Ltd [1998], unreported, County Court of Victoria (Mullaly J), 16 December.

38. But see $R-v$-Civil and Civic Pty Ltd [1992], unreported, County Court of Victoria (Crossley J), 15 December.

39. Mullaly P. Victorian sentencing manual. 2nd edition. Melbourne: Law Crest, 1999.

40. $R-v$-Wiltshire and Rattray Haynes Industries Pty Ltd [1990], unreported, County Court of Victoria, (Dee J), 29 November.

41. Singleton (VWA) - $v$-Fletcher Construction Australia Ltd [1999], unreported, County Court of Victoria (Rizkalla J), 26 February.

42. WorkCover Authority of NSW -v-Waugh [1995] 59 IR 89: 100.

43. DPP - $v$ - Pacific Dunlop Ltd [1994], unreported, County Court of Victoria (Mullaly J), 28 June: 93.

44. WorkCover Authority (NSW) (Inspector Page) - v- Walco Hoists Rentals Pty Ltd (No. 2) [2000] 99 IR 163: 185. The 'objective' factor includes 'the nature and quality of the offence, and the clear policy of the Act in relation to the establishment of safe standards and the protection of the workforce.'

45. See, for example, $R-v$ - A C Hatrick Chemicals Pty Ltd \& Ors [1995], unreported, Supreme Court of Victoria (Hampel J), 8 December.

46. $R-v$ - Granowski [1996], unreported, County Court of Victoria, 23 February.

47. But see $R-v$ - Natra Pty Ltd [1999], unreported, County Court of Victoria (Barnett J), 6 July, where the court appears to accept that penalty might be mitigated where a machine has been inspected without comment by the OSH inspectorate.

48. DPP -v-Melbourne Excavations and Demolitions Pty Ltd [1996], County Court of Victoria (Howse J), 20 November. 
49. For a discussion of the application of the principle of parity in sentencing OSH offenders in New South Wales, see Thompson W. Understanding New South Wales occupational health and safety legislation. 3rd edition. Sydney: CCH, 2001: 61.

50. Stratton - $v$ - Bestaburgh Pty Ltd [1994], unreported, Supreme Court of Victoria (Hansen J), 9 September.

51. See also DPP - $v$ - Pacific Dunlop Tyres Pty Ltd and Goodyear Tyres Pty Ltd, trading as South Pacific Tyres [1991], unreported, County Court of Victoria (Fricke J), 22 November.

52. Mullaly P. Victorian sentencing manual. 2nd edition. Melbourne: Law Crest: 699.

53. $R-v$-Natra Pty Ltd [1995], unreported, County Court of Victoria (Nixon J), 27 June.

54. $R-v-F$ Howe \& Son (Engineers) Ltd [1999] 2 All ER 249.

55. For a case interpreting the operation of the provisions for additional penalties for repeat offences in section 53 of the OHSA, see DPP - v-ESSO Australia Pty Ltd [2001] 107 IR 285: 290-291.

56. Compare $R-v$ - Nylex Corporation Ltd [1997], unreported, County Court of Victoria (Hassett J), 24 November.

57. Gunningham N and Johnstone R. Systems and sanctions: regulating workplace safety. Oxford: Oxford University Press, 1999: chapters 4, 6 and 7.

58. Victorian WorkCover Authority. Recent prosecutions 2000. Melbourne: Victorian WorkCover Authority, 2001.

59. Victorian WorkCover Authority. Recent prosecutions 2001. Melbourne: Victorian WorkCover Authority, 2002.

60. Sargent N. Law, ideology and corporate crime: a critique of instrumentalism. Canadian Journal of Law and Society 1989; 39 (4): 39-75.

61. McBarnet D. Conviction. Law, the state and the construction of justice. London: Macmillan, 1981: 148.

62. Sargent N. Law, ideology, social change: an analysis of the role of law in the construction of corporate crime. The Journal of Social Justice 1990; 1: 97, 105-106.

63. Hunt A. The ideology of law: advances and problems in recent applications of the concept of ideology to the analysis of law. Law and Society Review 1985; 19: 11.

64. McBarnet D. Conviction. Law, the state and the construction of justice. London: Macmillan, 1981: 155-162.

65. See also Norrie A. Crime, reason and history: a critical introduction to criminal law. London: Weidenfeld and Nicolson, 1993: 88-89.

66. See also Tombs S. Understanding regulation? Social and Legal Studies 2002; 11 (1): 111-131.

67. See also Croall's work in relation to consumer prosecutions: Croall H. Mistakes, accidents, and someone else's fault: the trading offender in court. Journal of Law and Society 1988; 15 (3): 293.

68. Carson W G. White collar crime and the enforcement of factory legislation. British Journal of Criminology 1970; 10: 383.

69. Carson W G. Some sociological aspects of strict liability and the enforcement of factory legislation. Modern Law Review 1970; 33: 396.

70. McBarnet D. Conviction. Law, the state and the construction of justice. London: Macmillan, 1981: 138-140.

71. See also Jensen P L. Assessing assessment: the Danish experience of workers' participation in risk assessment. Economic and Industrial Democracy 2002; 23 (2): 201-227.

72. Gunningham N and Johnstone R. Systems and sanctions: regulating workplace safety. Oxford: Oxford University Press, 1999: chapter 7. 
73. Offe C. The theory of the capitalist state and the problem of policy formation. In: Lindberg L N (ed). Stress and contradictions in modern capitalism. Public policy and the theory of the state. Lexington, Mass: Lexington Books, 1975.

74. See also Tombs S. Law, resistance and reform: 'regulating' safety crimes in the UK. Social and Legal Studies 1995; 4 (3): 343-366.

75. Simpson G and Charlesworth H. Objecting to objectivity. In: Hunter R, Ingleby R and Johnstone $\mathrm{R}$ (eds). Thinking about law: perspectives on the history, philosophy and sociology of law. Sydney: Allen \& Unwin, 1995.

76. Sargent N. Law, ideology, social change: an analysis of the role of law in the construction of corporate crime. The Journal of Social Justice 1990; 1: 97; see also page 99, where reference is made to Bierne P and Quinney R (eds). Marxism and law. New York: John Wiley and Sons, 1982.

77. Sargent N. Law, ideology, social change: an analysis of the role of law in the construction of corporate crime. The Journal of Social Justice 1990; 1: 97, 101.

78. As might be suggested by the Robens Report itself; see Robens (Lord). Safety and health at work. Report of the committee (1970-1972). London: HMSO, 1972: 82.

79. For an early attempt at this reconstruction, see Gunningham $\mathrm{N}$ and Johnstone R. Systems and sanctions: regulating workplace safety. Oxford: Oxford University Press, 1999: chapters 6 and 7.

80. See Tombs S. Understanding regulation? Social and Legal Studies 2002; 11 (1): 111-131; also, see references on pages 126-128. 